experiments with $200 \mathrm{mgnu}$. of thio-urea daily for ten days have produced similar results. The changes in both thyroid and pituitary are similar to those produced by feeding rats a diet containing rape seed $^{2,3}$.

Thyroid Research Department,

T. H. KENNEDY.

New Zealand Medical Research Council,

University of Otago Medical School,

Dunedin, N.Z.

June 8.

1 Hercus, C. E., and Purves, H. D., J. Hyg. (Camb.) 36, 182 (1936).

2 Kennedy, T. H., and Purves, H. D, Brit. J. Exp. Path., 22, 241 (1941).

${ }^{3}$ Griesbach, W. E., Brit. J. Exp. Path., 22, 245 (1941).

\section{Oxidation by Copper in Alcoholic Medium}

Nor many examples of redox catalysis in nonaqueous solutions are known. The oxidation of ascorbic acid by copper in absolute ethyl alcohol is interesting because in many respects it resembles the corresponding oxidation in aqueous systems. In the experiments to be described, the absolute alcohol solution of ascorbic acid contained $1 \mathrm{mgm}$. of the acid per $2 \mathrm{ml}$. After the oxidation, the unchanged ascorbic acid was estimated by dichlorphenolindophenol titration of a $2 \mathrm{ml}$. sample diluted by addition of $10 \mathrm{ml}$. of 0.5 per cent aqueous acetic acid.

No data concerning the solubility of copper sulphate in absolute ethyl alcohol could be found in the available literature. This has been determined by weighing the anhydrous salt remaining after careful evaporation of a saturated alcoholic solution of copper sulphate. The solubility of $\mathrm{CuSO}_{4} .5 \mathrm{H}_{2} \mathrm{O}$ at $17^{\circ} \mathrm{C}$. was found to be 0.0045 per cent, that of anhydrous $\mathrm{CuSO}_{4}, 0.009$ per cent.

\begin{tabular}{|c|c|c|c|}
\hline Sajt dissolved & $\begin{array}{c}\text { Conc. of } \\
\mathrm{CuSO}_{4}\end{array}$ & $\begin{array}{l}\text { \% Oxidation } \\
\text { after } 5 \mathrm{hr} .\end{array}$ & $\begin{array}{c}\text { \% Oxidation } \\
\text { in the presence } \\
\text { of } 5.7 \times 10^{-3} \\
\text { NaCl after } 5 \mathrm{hr} \text {. }\end{array}$ \\
\hline $\mathrm{CuSO}_{4} .5 \mathrm{H}_{2} \mathrm{O}$ & $1.9 \times 10^{-6} M$ & 0 & 0 \\
\hline,$\quad$, & $9.5 \times 10^{-5} M$ & $63 \cdot 6$ & $27 \cdot 2$ \\
\hline Anhydrous $\mathrm{CuSO}_{4}$ & $3.8 \times 10^{-5} M$ & $40 \cdot 9$ & 0 \\
\hline , & $1.9 \times 10^{-4} M$ & $100 \cdot 0$ & $45 \cdot 4$ \\
\hline
\end{tabular}

Concentration of ascorbic acid $8.5 \times 10^{-4} M$ in all cases.

The catalytic action of copper sulphate is shown in the accompanying table. From this table also the inhibiting influence of sodium chloride can be seen. This influence is identical with the action of sodium chloride in aqueous systems.

Even greater than the activation of copper sulphate alone is that given by the pyridine-copper sulphate complex obtained by the action of pure pyridine on anhydrous copper sulphate and evaporation of the excess of pyridine. The crystalline salt so obtained was deep blue in colour and similar to salts obtained by Lang ${ }^{1}$. It contained $\mathrm{CuSO}_{4}$ and pyridine in equimolar proportions. The solubility of this complex in absolute alcohol is 0.022 per cent, giving a greater amount of $\mathrm{CuSO}_{4}$ in solution than did copper sulphate alone.

At a concentration of anhydrous copper sulphate of $8 \cdot C 4 \times 10^{-5}, 35.7$ per cent of ascorbic acid was oxidized during six hours; at a concentration of copper sulphate - pyridine complex corresponding to a $\mathrm{CuSO}_{4}$ concentration of $9.06 \times 10^{-5}, 100$ per cent oxidation was found after 15 minutes.

Pyridine alone has also a catalytic effect, the con- centration required to produce a given amount of oxidation being 1,000 times as great as that of copper sulphate.

It is noteworthy that these effects of pyridine and pyridine - copper sulphate complex in alcohol are quite different from those in aqueous systems, where pyridine alone (possibly by binding $\mathrm{Cu}$ ) inhibits ascorbic acid oxidation, and the copper sulphatepyridine complex is much less active than corresponding concentrations of copper sulphate alone.

Water present in alcoholic systems up to 1 per cent has no influence on the rate of oxidation. Higher percentages activate the oxidation, but this phenomenon is complicated by $p \mathrm{H}$ changes.

A full account of the work with the theoretical considerations will be published elsewhere.

E. M. MystK owski.

Medical Chemistry Department,

The University, Edinburgh.

${ }^{1}$ Lang, W., Berichte, 21, 1578 (1888).

\section{Percentage of Water in Jelly-Fish}

A LIVING specimen of Aurelia aurita about 4 in. in diameter was weighed by the displacement method $^{1}$ and the percentage of water found by distilling it under $x^{2} \operatorname{lol}^{2}$. The result was: water, 95.56 per cent; residue, 3.87 per cent; giving a difference of 0.57 per cent.

Since the distillation was carried out in what was practically a closed still, nothing should be lost. The difference, 0.57 per cent, represents $(a)$ a trace of fat or other material dissolved by the xylol, and $(b)$ a trace of water adhering to the rather large vessel which had to be used. The gonads would contain a trace of fat. The residue consists of salts, $3 \cdot 2$ per cent, leaving 0.67 per cent of dry protein; and since living material, such as muscle, in most marine animals, approximates to water 80 per cent and protein 15 per cent, we conclude that the 0.67 per cent of dry protein corresponds to about 4 per cent of protoplasm.

A number of distillations were carried out giving similar results, and it was intended to clinch the matter by carrying out a Kjeldahl estimation for nitrogen, but unfortunately no more living specimens arrived in the laboratory.

Some rather misleading statements have been made about Aurelia, and unfortunately these are finding their way into text-books. It has been stated that "The jelly-fish contains 99.8 per cent of water" and "The organic material in the body of medusæ amounts to less than 1 and most often to less than $\frac{1}{2}$ per cent". Bateman ${ }^{3}$ has criticized the first statement and shown it to be incorrect, but from theoretical grounds alone $99 \cdot 8$ per cent water is an impossible figure for Aurelia, for $(a)$ an animal comprising 99.8 per cent water would float in the sea with a substantial portion of its body out of the water, which Aurelia does not do; (b) the density of Aurelia has been found, and it is obviously close to that of sea-water, which is 1.027 at $13^{\circ} \mathrm{C}$. at Plymouth; if Aurelia were composed of 99.8 per cent water with a density of 0.99941 , the density of the remaining $0 \cdot 2$ per cent would have to exceed that of mercury (c) since Plymouth sea-water itself contains only 96.8 per cent of distilled water, surely this is the upper limit for any marine organism living in it.

We may conclude therefore that Aurelia comprises 